\title{
PREDICTORS OF MENTAL HEALTH IN FEMALE TEACHERS
}

\section{REINGARD SEIBT ${ }^{1}$, SILVIA SPITZER ${ }^{1}$, DIANA DRUSCHKE ${ }^{1}$, KLAUS SCHEUCH ${ }^{1}$, and ANDREAS HINZ ${ }^{2}$}

\author{
${ }^{1}$ Technical University of Dresden, Dresden, Germany \\ Institute and Clinic of Occupational and Social Medicine \\ ${ }^{2}$ University of Leipzig, Leipzig, Germany \\ Department of Medical Psychology and Medical Sociology
}

\begin{abstract}
Objective: Teaching profession is characterised by an above-average rate of psychosomatic and mental health impairment due to work-related stress. The aim of the study was to identify predictors of mental health in female teachers. Material and Methods: A sample of 630 female teachers (average age $47 \pm 7$ years) participated in a screening diagnostic inventory. Mental health was surveyed with the General Health Questionnaire GHQ-12. The following parameters were measured: specific work conditions (teacher-specific occupational history), scales of the Effort-Reward-Imbalance (ERI) Questionnaire as well as cardiovascular risk factors, physical complaints (BFB) and personal factors such as inability to recover (FABA), sense of coherence (SOC) and health behaviour. Results: First, mentally fit $\left(\mathrm{MH}^{+}\right)$and mentally impaired teachers $\left(\mathrm{MH}^{-}\right)$were differentiated based on the GHQ-12 sum score $\left(\mathrm{MH}^{+}:<5 ; \mathrm{MH}^{-}: \geq 5\right) ; 18 \%$ of the teachers showed evidence of mental impairment. There were no differences concerning work-related and cardiovascular risk factors as well as health behaviour between $\mathrm{MH}^{+}$and $\mathrm{MH}^{-}$. Binary logistic regressions identified 4 predictors that showed a significant effect on mental health. The effort-reward-ratio proved to be the most relevant predictor, while physical complaints as well as inability to recover and sense of coherence were identified as advanced predictors (explanation of variance: $23 \%$ ). Conclusion: Contrary to the expectations, classic work-related factors can hardly contribute to the explanation of mental health. Additionally, cardiovascular risk factors and health behaviour have no relevant influence. However, effort-rewardratio, physical complaints and personal factors are of considerable influence on mental health in teachers. These relevant predictors should become a part of preventive arrangements for the conservation of teachers' health in the future.
\end{abstract}

\section{Key words:}

Mental health, Female school teacher, Work stress, Personal factor, Predictor

\section{INTRODUCTION}

Recent follow-up studies indicate that psychosocial work environment is important for mental health [1]. Especially the perceived psychosocial job strain is related to clinically significant psychiatric disorders [2] that have a major impact on long-term disability, dependency, sick leaves, loss of productivity and mortality.

The state of health of the German school teachers is conspicuously impaired, especially by mental disorders and psychosomatic diseases [3-6]. In particular, this situation is reflected by a high percentage of early retirements. Reasons for such a situation are seen in psychiatric and psychosomatic diseases which can be traced back to the high work-related mental stress.

However, the stress problem among teachers is not restricted to Germany but it is widespread in the whole world and predominantly in European countries (i.e. England [7], France [8], Ireland [9], Italy [10], Netherlands [11]).

Received: November 19, 2012. Accepted: November 21, 2013.

Corresponding author: R. Seibt, Technical University of Dresden, Institute and Clinic of Occupational and Social Medicine, Fetscherstrasse 74, D-01307 Dresden, Germany (e-mail: reingard.seibt@mailbox.tu-dresden.de). 
In the national and international literature on the level and major sources of mental health among teachers, several authors have consistently found evidence that mental health of school teachers is seriously affected by workrelated stress [4-6,12-19]. A large study of 949 teachers found high degrees of burnout symptoms such as emotional exhaustion, depersonalization and low personal accomplishment, measured with the Maslach Burnout Inventory [6]. Biological pathways are discussed as putative mediators between chronic work stress and health impairments [12].

Teachers working in secondary schools feel more emotional exhaustion than teachers from grammar schools, and parttime teachers are more affected by loss of personal accomplishment than the ones working full-time. Male teachers show more depersonalization than female teachers [6]. Gender and school type have no significant impact on work stress, measured with the Effort-Reward Imbalance questionnaire, but older teachers show significantly more work stress than the younger ones [6]. Another study [5] focused on the relationship between part-time and full-time positions. The teachers in part-time jobs have only slightly lower stress levels than those in full-time jobs, also measured with the Effort-Reward Imbalance questionnaire. In that study, neither the working conditions nor the volume of employment significantly predicted health status.

Majority of the studies on work-related stress of teachers focus on the socio-demographic characteristics (age, gender, etc.) and the working conditions (workload, pupils behaviour, organisational school culture, etc.). However, there are only few studies examining how personal factors predict mental health among teachers as well as there are only few studies that include work-related and personal factors at the same time. Studies on inefficient coping strategies [20] that complicate the compensation of job specific stress are also missing.

The following work-related factors were identified as the sources of stress and stress-related disorders in the teaching profession: high workload and working time, behavioural problems of pupils, poor organisational school culture, poor working conditions (i.e. too many pupils in a class, noise during the lessons, time pressure, behaviour of parents), a low degree of autonomy as well as different expectations of pupils and parents from the teachers [5-7,9,21]. Furthermore, insufficient material and spatial equipment and the negative perception and evaluation of the teachers' profession in society are regarded as sources of a negative strain. In comparison with other professions, the workload is sometimes misinterpreted and positive aspects of the teaching profession (variety of tasks, etc.) are neglected.

Against this backdrop, the aim of this study was to examine female school teachers (in this paper referred to as 'teachers') with regard to their state of mental health and current working conditions, physical health and personal factors. We investigated which of these factors allow to distinguish teachers who are suffering from impaired mental health from those who are not. The hypothesis is that personal factors are as much related to mental health as "classic" working conditions.

\section{METHODS}

\section{Sample}

The examination was carried out in the context of preventive occupational-medical and psychological check-ups conducted between 2006 and 2008. Every teacher in Germany is required by law to be offered this screening diagnostic inventory but participation is on a voluntary basis, which means selection effects cannot be eliminated.

All public schools in a defined district of Saxony (Germany) were contacted by the collaborators. A total of 787 teachers from general public schools, aged 29 to 62 years participated in this screening diagnostic inventory (participation rate: $73 \%$ ) and their average age was $47 \pm 7$ years. A small number of male teachers, trainee teachers and 
participants with incomplete data were excluded from the analyses. Thus, finally, the sample consisted of 630 female teachers. $42 \%$ of them were employed part-time, working 50-70\% of the volume of a full-time employee.

Participation in the preventive occupational-medical and psychological check-ups was voluntarily for all teachers. We informed the participants about the aims and methods of the study. All participants gave their written informed consent. They had the possibility to terminate their participation without any consequences at any time of the study realization. The data were made anonymous and treated in a secure and strictly confidential manner. The necessary ethics committee approval was provided by the Sächsische Bildungsagentur.

\section{Examination instruments}

The screening diagnostic inventory consisted of a teacherspecific occupational history, standardised questionnaires and medical measurements. Moreover, socio-demographic data (e.g. age, marital status) and anamnestic factors were assessed.

\section{Mental health}

Mental health was assessed with the (German) short version of the General Health Questionnaire-12, the GHQ-12 [22]. This GHQ is a valid screening questionnaire for mental health problems and minor psychological impairments [23]. It is based on the self-reported state of well-being in the past 4 weeks in relation to general wellbeing. The symptoms are estimated according to a 4-step answering scale ('not at all', 'same as usual', 'rather more than usual' and 'much more than usual') and evaluated by the classic 'GHQ-scoring' [23], resulting in a sum score between 0 (mentally fit) and 12 (impaired mental health). Following Üstün and Sartorius [24], a GHQ value equal to or above 5 as a cut-off for impaired psychological health was used.

\section{Working factors}

Working tasks, working conditions and the subscales of effort and reward were taken into consideration. The working tasks and conditions were assessed with a teacherspecific occupational history. The teachers were asked, for example, about the type of school, class sizes, subjects, total number of weekly lessons, time required for additional and extra-curricular activities, and total working hours per week (see notes Table 1).

The subscales of effort, reward and the effort-rewardratio (ERI ratio) were measured with the short version of the Effort-Reward-Imbalance Questionnaire (ERI [25]). In total it comprised 17 items, including 6 items on the effort scale and 11 items on the reward scale. Effort (range: 6-30; high values indicate high effort at work) refers to the perceived time pressure, work interruptions

Table 1. Work-related factors at school among the mentally fit $\left(\mathrm{MH}^{+}\right)$and mentally impaired teachers $\left(\mathrm{MH}^{-}\right)$

\begin{tabular}{|c|c|c|c|c|}
\hline \multirow[b]{2}{*}{ Examined characteristics } & \multicolumn{2}{|c|}{ Teacher groups } & \multicolumn{2}{|c|}{ Significance } \\
\hline & $\begin{array}{c}\mathrm{MH}^{+} \\
(\mathrm{N}=517)\end{array}$ & $\begin{array}{c}\mathrm{MH}^{-} \\
(\mathrm{N}=113)\end{array}$ & test statistic & $\begin{array}{c}\mathrm{p} \\
\text { effect size }\end{array}$ \\
\hline \multicolumn{5}{|l|}{$\begin{array}{l}\text { Working tasks and conditions }{ }^{1}, \mathrm{AV} \pm \mathrm{SD} \\
\text { additional activities }^{\mathrm{a}}\end{array}$} \\
\hline number (quantity) & $2.5 \pm 1.3$ & $2.5 \pm 1.2$ & $\begin{array}{c}\mathrm{U}=29187.50 \\
\mathrm{Z}=0.01\end{array}$ & 0.989 \\
\hline duration (h/week) & $3.6 \pm 3.3$ & $3.6 \pm 4.3$ & $\begin{array}{c}\mathrm{U}=28666.00 \\
\mathrm{Z}=0.31\end{array}$ & 0.754 \\
\hline
\end{tabular}


Table 1. Work-related factors at school among the mentally fit $\left(\mathrm{MH}^{+}\right)$and mentally impaired teachers $\left(\mathrm{MH}^{-}\right)$- cont.

\begin{tabular}{|c|c|c|c|c|}
\hline \multirow[b]{2}{*}{ Examined characteristics } & \multicolumn{2}{|c|}{ Teacher groups } & \multicolumn{2}{|c|}{ Significance } \\
\hline & $\begin{array}{c}\mathrm{MH}^{+} \\
(\mathrm{N}=517)\end{array}$ & $\begin{array}{c}\mathrm{MH}^{-} \\
(\mathrm{N}=113)\end{array}$ & test statistic & $\begin{array}{c}\mathrm{p} \\
\text { effect size }\end{array}$ \\
\hline preparation and follow-up of lessons (h/week) & $9.0 \pm 5.0$ & $9.6 \pm 5.1$ & $\begin{array}{c}\mathrm{U}=27366.00 \\
\mathrm{Z}=1.06\end{array}$ & 0.289 \\
\hline \multicolumn{5}{|l|}{ extra-curricular activities ${ }^{\mathrm{b}}$} \\
\hline duration (h/week) & $18.7 \pm 7.6$ & $20.5 \pm 8.7$ & $\begin{array}{c}U=25812.50 \\
Z=1.94\end{array}$ & 0.052 \\
\hline Class size (number of pupils), $\mathrm{AV} \pm \mathrm{SD}$ & $19.4 \pm 3.6$ & $19.8 \pm 3.6$ & $\begin{array}{c}\mathrm{U}=26242.00 \\
\mathrm{Z}=1.69\end{array}$ & 0.090 \\
\hline Class level, $\mathrm{AV} \pm \mathrm{SD}$ & $3.6 \pm 1.4$ & $3.7 \pm 1.4$ & $\begin{array}{c}\mathrm{U}=28761.50 \\
\mathrm{Z}=0.26\end{array}$ & 0.793 \\
\hline School lessons $=45 \mathrm{~min}$ (lessons/week), $\mathrm{AV} \pm \mathrm{SD}$ & $14.6 \pm 2.9$ & $14.8 \pm 2.4$ & $\begin{array}{c}\mathrm{U}=28873.50 \\
\mathrm{Z}=0.19\end{array}$ & 0.847 \\
\hline Total working hours (h/week), $\mathrm{AV} \pm \mathrm{SD}^{\mathrm{c}}$ & $39.4 \pm 9.7$ & $41.7 \pm 10.6$ & $\begin{array}{c}\mathrm{U}=69479.50 \\
\mathrm{Z}=1.80\end{array}$ & 0.071 \\
\hline \multicolumn{5}{|l|}{ Scales of effort-reward questionnaire ${ }^{2}$} \\
\hline effort (range of values: 6-30), $\mathrm{AV} \pm \mathrm{SD}$ & $14.4 \pm 3.8$ & $17.1 \pm 4.2$ & $\begin{array}{c}\mathrm{U}=17894.00 \\
\mathrm{Z}=6.48\end{array}$ & $\begin{array}{c}<0.001 \\
\mathrm{r}_{\mathrm{pb}}=0.26\end{array}$ \\
\hline reward (range of values: $11-55), \mathrm{AV} \pm \mathrm{SD}$ & $46.3 \pm 6.3$ & $42.7 \pm 7.4$ & $\begin{array}{c}\mathrm{U}=20632.50 \\
\mathrm{Z}=4.90\end{array}$ & $\begin{array}{c}<0.001 \\
\mathrm{r}_{\mathrm{pb}}=-0.20\end{array}$ \\
\hline status (range of values: 4-20), $\mathrm{AV} \pm \mathrm{SD}$ & $16.6 \pm 2.8$ & $15.7 \pm 3.2$ & $\begin{array}{c}\mathrm{U}=23754.50 \\
\mathrm{Z}=3.14\end{array}$ & $\begin{array}{c}0.002 \\
\mathrm{r}_{\mathrm{pb}}=-0.13\end{array}$ \\
\hline esteem (range of values: $5-25), \mathrm{AV} \pm \mathrm{SD}$ & $22.2 \pm 3.4$ & $20.4 \pm 4.3$ & $\begin{array}{c}\mathrm{U}=22109.00 \\
\mathrm{Z}=4.19\end{array}$ & $\begin{array}{c}<0.001 \\
r_{p b}=-0.17\end{array}$ \\
\hline job security (range of values: $2-10), \mathrm{AV} \pm \mathrm{SD}$ & $7.5 \pm 2.5$ & $6.6 \pm 2.7$ & $\begin{array}{c}\mathrm{U}=23397.00 \\
\mathrm{Z}=3.43\end{array}$ & $\begin{array}{c}0.001 \\
\mathrm{r}_{\mathrm{pb}}=-0.14\end{array}$ \\
\hline ERI ratio, $\mathrm{AV} \pm \mathrm{SD}$ & $0.6 \pm 0.2$ & $0.8 \pm 0.3$ & $\begin{array}{c}\mathrm{U}=17335.50 \\
\mathrm{Z}=6.76\end{array}$ & $\begin{array}{c}<0.001 \\
\mathrm{r}_{\mathrm{pb}}=0.27\end{array}$ \\
\hline ERI risk group $($ ERI $>1), \mathrm{n}(\%)^{2}$ & $21(4.1)$ & $22(19.5)$ & $\chi^{2}=34.61$ & $\begin{array}{c}<0.001 \\
\mathrm{~d}=0.48\end{array}$ \\
\hline
\end{tabular}

${ }^{1}$ Questionnaire of occupational and medical history.

${ }^{2}$ Questionnaire of effort-reward-imbalance.

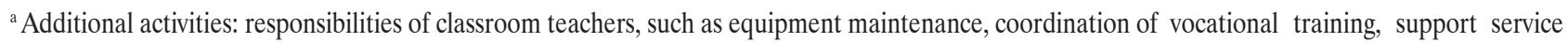
for a subject and other support services.

${ }^{\mathrm{b}}$ Extra-curricular activities: preparing school lessons, correcting class tests, time spent participating in conferences, communicating with parents and pupils, and administrative duties.

${ }^{c}$ Weekly total working hours: sum of the number of lessons, time for standing in other teachers or as teachers in charge, additional and extra-curricular activities as well as the time spent commuting between separated school buildings.

$\mathrm{AV}$ - mean; SD - standard deviation.

U - U-Test: Mann and Whitney; $z$ : $z$-value; $\chi^{2}$ : frequencies, Chi²-test (Pearson).

$\mathrm{r}_{\mathrm{pb}}$ - estimator of effect size of U-test (point-biserial correlation coefficient).

$\mathrm{d}$ - estimator of effect size $\mathrm{Chi}^{2}$-test. 
and disturbances, responsibility at work, overtime work, etc.; while reward (range: 11-55; high values indicate a high level of reward) measures satisfaction with financial status and related aspects, esteem rewards and job security. A sum score of these ratings is calculated for each scale. The items are measured with a 5-point Likert scale ranging from 'agree' to 'disagree'.

If there is a high effort and a low reward, this effect results in a high ERI ratio (gratification crisis). If the ERI ratio is higher than 1, health risks can be expected (the higher the imbalance, the higher the health risk).

\section{Physical health status}

Within physical health components, the cardiovascular risk factors and the self-reported current physical complaints were assessed.

Blood pressure, body mass index, waist circumference and fitness were considered as risk factors for cardiovascular diseases (for the standardized screening method see Seibt et al. [26]). For examination of the cardiovascular fitness, a submaximal ergometer test was used. This test included measurements of rest and load pulse rates [bpm] and load time [s]. The load pulse rate was measured directly after finishing the exercise (see notes Table 2).

Current complaints were assessed with the complaints questionnaire BFB [27]. This questionnaire (answer forms: $0=$ no, 1 = yes) consists of a physical (41 items) and psychological (28 items) subscales concerning complaints which can permanently impair well-being. The responses were separated by the number and nature of complaints (discomfort pattern).

\section{Personal factors}

The incapacity to recover, sense of coherence and health behaviour were included as personal factors.

The inability to recover was examined using the corresponding subscale from the standardized FABA questionnaire [28]. The score of relaxation inability (RI) consisted of 6 items referring to the inability to relax after work but also gave information on risk assessment in relation to inefficient coping with demands. The range of this score was between 6 and 24 (high values indicated a high relaxation inability). The general cut-off for "noticeable" values was 19 and for "very noticeable" values it was 21.

The sense of coherence (SOC) was considered within the framework of Antonovsky's salutogenetic model as a dispositional resource for coping with demands. The SOC was assessed with the Leipzig short Scale SOC-L9 [29], conceptualized as a valid unidimensional scale. This scale consists of only 9 items that are answered on a 7-point Likert scale. The higher this sum score, the higher the degree of SOC.

Health behaviour and anamnestic factors (sports, smoking, consumption of alcohol, unfavourable nutritional behaviour, behaviour at leisure time, etc.) were assessed by means of a self-made medical history.

\section{Statistical analyses}

All analyses were performed using commercially available software (SPSS for Windows, release 19.0). Descriptive analyses included mean and standard deviations for quantitative measures and percentages for categorical variables. Normal distribution was assessed by inspecting skewness and kurtosis of the respective residuals (normal distribution: -1 and +1 ). Comparisons between the subgroups were conducted using the Mann-Whitney or Chisquare test. The level of significance was 0.05 (two-sided) for all statistical tests. Additionally, the effect size was calculated for all the analyses by quantifying the size of the difference between the 2 teacher groups.

To determine potential work-related, physical health and personal predictors and to weigh positive and negative influences on mental health, correlation analyses were calculated as a first step and then extended to include binary logistic regression analyses [30]. The associations between variables described by the correlation coefficients were 
interpreted as follows [31]: none: $0.00-0.09$; small: 0.10 0.30; medium: 0.30-0.50; large: 0.50-1.00.

Binary logistic regression is a regression that applies to binary $(0,1)$ variables. This regression analyses are used for predicting the categorical criterion variable mental health (outcome) based on significant work-related, physical health and personal predictors. The predictor variables are continuous and categorical.

\section{RESULTS}

\section{Comparison between the mentally fit and mentally impaired teachers}

First, we attempted to identify which factors (working tasks and conditions, physical health and personality traits) distinguish the mentally fit $\left(\mathrm{MH}^{+}\right)$from mentally impaired teachers $\left(\mathrm{MH}^{-}\right)$.

\section{Mental health}

Of the assessed teachers, $18 \%$ showed evidence of mental impairment (GHQ-12 sum score: $\geq 5$ ). The mean of the GHQ-12 sum score of the mentally fit teachers was 1.2 (median: $1 ; \mathrm{Q}_{25}-\mathrm{Q}_{75}=0-2$ ) and that of the teachers with impaired mental health was 7.0 (median: 7; $\mathrm{Q}_{25}-\mathrm{Q}_{75}=6-8$ ).

\section{Working factors}

Regarding working tasks and conditions at school, the mentally fit teachers did not differ significantly from the impaired ones (Table 1). The mentally impaired teachers reported a slightly higher total number of weekly lessons (42 h/week), which is especially due to a higher work effort required for extra-curricular activities. Here, they reported spending more time ( $21 \mathrm{~h} /$ week) on the preparation of and going over the lessons, correction and marking tests as well as extra-curricular activities with pupils and parents. The sample reflects the relationship between occupational effort and reward and mental well-being in a significantly elevated ERI ratio of the mentally impaired teachers. They have higher values in the effort scale and lower values in the reward scale as well as the corresponding subscales appreciation, job security and money or career opportunities. $4 \%$ of the mentally fit teachers were classified as belonging to the ERI risk group (ERI: $>1$ ), in the group of mentally impaired teachers there were $20 \%$ (Tables 1-3).

Table 2. Physical health factors among the mentally fit $\left(\mathrm{MH}^{+}\right)$and mentally impaired teachers $\left(\mathrm{MH}^{-}\right)$

\begin{tabular}{|c|c|c|c|c|}
\hline \multirow{2}{*}{$\begin{array}{c}\text { Analysed risk factors } \\
\text { for cardiovascular diseases }\end{array}$} & \multicolumn{2}{|c|}{ Teacher groups } & \multicolumn{2}{|c|}{ Significance } \\
\hline & $\begin{array}{c}\mathrm{MH}^{+} \\
(\mathrm{N}=517)\end{array}$ & $\begin{array}{c}\mathrm{MH}^{-} \\
(\mathrm{N}=113)\end{array}$ & test statistic & $\begin{array}{c}\mathrm{p} \\
\text { effect size }\end{array}$ \\
\hline \multicolumn{5}{|l|}{ Blood pressure $^{1}$} \\
\hline systolic blood pressure (mmHg), $\mathrm{AV} \pm \mathrm{SD}$ & $131.5 \pm 17.3$ & $130.7 \pm 15.2$ & $\begin{array}{c}\mathrm{U}=29158.5 \\
\mathrm{Z}=0.03\end{array}$ & $\begin{array}{c}0.976 \\
r_{p b}=0.00\end{array}$ \\
\hline diastolic blood pressure $(\mathrm{mmHg}), \mathrm{AV} \pm \mathrm{SD}$ & $89.6 \pm 11.4$ & $89.4 \pm 11.5$ & $\begin{array}{c}\mathrm{U}=28894.0 \\
\mathrm{Z}=0.18\end{array}$ & $\begin{array}{c}0.857 \\
r_{p b}=0.01\end{array}$ \\
\hline hypertension ( $\geq 140 / 90 \mathrm{mmHg}), \mathrm{n}(\%)^{1}$ & $259(50.1)$ & $61(54.0)$ & $\chi^{2}=0.56$ & 0.454 \\
\hline antihypertensive medication $\mathrm{n}(\%)$ & $93(18.0)$ & $19(16.8)$ & $\chi^{2}=0.09$ & 0.767 \\
\hline \multicolumn{5}{|l|}{ Body measures ${ }^{2}$} \\
\hline Body Mass Index (BMI) $\left(\mathrm{kg} / \mathrm{m}^{2}\right), \mathrm{AV} \pm \mathrm{SD}$ & $24.8 \pm 4.1$ & $25.8 \pm 4.4$ & $\begin{array}{c}\mathrm{U}=25287.00 \\
\mathrm{Z}=2.24\end{array}$ & $\begin{array}{c}0.025^{*} \\
r_{p b}=0.09\end{array}$ \\
\hline overweight $(\mathrm{BMI} \geq 25), \mathrm{n}(\%)^{2}$ & $146(28.2)$ & $34(30.1)$ & $\chi^{2}=3.78$ & 0.286 \\
\hline $\operatorname{adiposity}(\mathrm{BMI} \geq 30), \mathrm{n}(\%)^{2}$ & $58(11.2)$ & $18(15.9)$ & & \\
\hline
\end{tabular}


Table 2. Physical health factors among the mentally fit $\left(\mathrm{MH}^{+}\right)$and mentally impaired teachers $\left(\mathrm{MH}^{-}\right)-$cont.

\begin{tabular}{|c|c|c|c|c|}
\hline \multirow{2}{*}{$\begin{array}{c}\text { Analysed risk factors } \\
\text { for cardiovascular diseases }\end{array}$} & \multicolumn{2}{|c|}{ Teacher groups } & \multicolumn{2}{|c|}{ Significance } \\
\hline & $\begin{array}{c}\mathrm{MH}^{+} \\
(\mathrm{N}=517)\end{array}$ & $\begin{array}{c}\mathrm{MH}^{-} \\
(\mathrm{N}=113) \\
\end{array}$ & test statistic & $\begin{array}{c}\mathrm{p} \\
\text { effect size }\end{array}$ \\
\hline body fat mass $(\mathrm{kg}), \mathrm{AV} \pm \mathrm{SD}$ & $22.4 \pm 8.5$ & $24.6 \pm 9.7$ & $\begin{array}{c}\mathrm{U}=25170.50 \\
\mathrm{Z}=2.22\end{array}$ & $\begin{array}{c}0.026^{*} \\
r_{p b}=0.09\end{array}$ \\
\hline waist hip ratio (WHR), $\mathrm{AV} \pm \mathrm{SD}$ & $0.82 \pm 0.06$ & $0.83 \pm 0.05$ & $\begin{array}{c}U=26310.50 \\
Z=1.65\end{array}$ & $\begin{array}{c}0.098 \\
\mathrm{r}_{\mathrm{pb}}=0.07\end{array}$ \\
\hline elevated health risk $(<0.85), \mathrm{n}(\%)$ & $148(28.6)$ & $40(35.4)$ & $\chi^{2}=2.03$ & 0.154 \\
\hline \multicolumn{5}{|l|}{ Fitness $^{\mathrm{a}}$} \\
\hline fitness index (PPI), $\mathrm{AV} \pm \mathrm{SD}$ & $1.9 \pm 0.6$ & $2.0 \pm 0.5$ & $\begin{array}{c}\mathrm{U}=19743.50 \\
\mathrm{Z}=1.64\end{array}$ & $\begin{array}{c}0.102 \\
r_{p b}=0.07\end{array}$ \\
\hline $\mathrm{PPI} \leq 1$ (poor), $\mathrm{n}(\%)$ & $39(7.5)$ & $9(8.0)$ & $\chi^{2}=0.08$ & 0.962 \\
\hline PPI > 2 (good), n $(\%)$ & $212(41.0)$ & $44(38.9)$ & & \\
\hline \multicolumn{5}{|l|}{ Complaints $^{\mathrm{b}}$} \\
\hline physical complaints (n) (range: $0-41$ ), $\mathrm{AV} \pm \mathrm{SD}$ & $7.0 \pm 5.5$ & $12.5 \pm 6.3$ & $\begin{array}{c}\mathrm{U}=14167.00 \\
\mathrm{Z}=8.60\end{array}$ & $\begin{array}{l}<0.001^{*} \\
r_{p b}=0.34\end{array}$ \\
\hline
\end{tabular}

${ }^{1}$ Guidelines for the Treatment of Arterial Hypertension [40].

${ }^{2}$ German Adiposity Association, German Diabetes Association [41].

${ }^{a}$ PPI - pulse performance index; PPI - load = rest pulse rate $(\mathrm{bpm}) /$ load time $(\mathrm{s})$. PPI $>2$ - good physical fitness,

PPI $\leq 1$ - bad fitness or inadequate training.

${ }^{\mathrm{b}}$ Questionnaire of complaints.

Other abbreviations as in Table 1.

Table 3. Personal factors among the mentally fit $\left(\mathrm{MH}^{+}\right)$and mentally impaired teachers $\left(\mathrm{MH}^{-}\right)$

\begin{tabular}{|c|c|c|c|c|}
\hline \multirow[b]{2}{*}{ Personal factors } & \multicolumn{2}{|c|}{ Teacher groups } & \multicolumn{2}{|c|}{ Significance } \\
\hline & $\begin{array}{c}\mathrm{MH}^{+} \\
(\mathrm{N}=517)\end{array}$ & $\begin{array}{c}\mathrm{MH}^{-} \\
(\mathrm{N}=113)\end{array}$ & test statistic & $\begin{array}{c}\mathrm{p} \\
\text { effect size }\end{array}$ \\
\hline \multicolumn{5}{|l|}{ Relaxation $^{1}$} \\
\hline relaxation inability (range: 6-24), $\mathrm{AV} \pm \mathrm{SD}$ & $15.2 \pm 3.6$ & $18.0 \pm 3.7$ & $\begin{array}{c}\mathrm{U}=16425.00 \\
\mathrm{Z}=7.31\end{array}$ & $\begin{array}{c}<0.001 \\
\mathrm{r}_{\mathrm{pb}}=0.29\end{array}$ \\
\hline noticeable / very noticeable values (> $18 \mathrm{pts}), \mathrm{n}(\%)$ & $97(18.8)$ & $55(47.8)$ & $\chi^{2}=42.87$ & $\begin{array}{l}<0.001 \\
\mathrm{~d}=0.53\end{array}$ \\
\hline \multicolumn{5}{|l|}{ Coherence $^{2}$} \\
\hline sense of coherence (range: 9-63), $\mathrm{AV} \pm \mathrm{SD}$ & $51.4 \pm 6.0$ & $46.9 \pm 6.6$ & $\begin{array}{c}\mathrm{U}=17271.50 \\
\mathrm{Z}=6.82\end{array}$ & $\begin{array}{c}<0.001 \\
r_{p b}=0.27\end{array}$ \\
\hline \multicolumn{5}{|l|}{$\begin{array}{l}\text { Health behaviour }{ }^{3} \\
\text { sports }\end{array}$} \\
\hline no or rare sporting activities, $\mathrm{n}(\%)$ & $135(26.1)$ & $32(28.3)$ & $\chi^{2}=2.53$ & 0.639 \\
\hline once a week, $\mathrm{n}(\%)$ & $159(30.8)$ & $32(28.3)$ & & \\
\hline twice a week or more, $\mathrm{n}(\%)$ & $223(43.1)$ & $49(43.4)$ & & \\
\hline
\end{tabular}


Table 3. Personal factors among the mentally fit $\left(\mathrm{MH}^{+}\right)$and mentally impaired teachers $\left(\mathrm{MH}^{-}\right)$- cont.

\begin{tabular}{lcccc}
\hline \multirow{2}{*}{ Personal factors } & \multicolumn{2}{c}{ Teacher groups } & \multicolumn{2}{c}{ Significance } \\
\cline { 2 - 5 } & $\begin{array}{c}\mathrm{MH}^{+} \\
(\mathrm{N}=517)\end{array}$ & $\begin{array}{c}\mathrm{MH}^{-} \\
(\mathrm{N}=113)\end{array}$ & test statistic & $\begin{array}{c}\mathrm{p} \\
\text { effect size }\end{array}$ \\
\hline duration (h/week), $\mathrm{AV} \pm \mathrm{SD}$ & $2.6 \pm 1.9$ & $2.6 \pm 2.0$ & $\mathrm{U}=28710.50$ & 0.774 \\
& & & $\mathrm{Z}=0.29$ & \\
smoking & & & \\
smoking (yes), $\mathrm{n}(\%)$ & $67(13.0)$ & $15(13.3)$ & $\chi^{2}=0.40$ & 0.817 \\
cigarettes (n/day), $\mathrm{AV} \pm \mathrm{SD}$ & $7.2 \pm 5.6$ & $5.0 \pm 4.1$ & $\mathrm{U}=29196.00$ & 0.989 \\
& & & $\mathrm{Z}=0.01$ & \\
alcohol intake & & & \\
sometimes, $\mathrm{n}(\%)$ & $468(90.5)$ & $107(94.7)$ & $\chi^{2}=3.18$ & 0.204 \\
regular, $\mathrm{n}(\%)$ & $22(4.3)$ & $1(0.9)$ & & \\
\hline
\end{tabular}

$\mathrm{r}_{\mathrm{pb}}=(1-2 \mathrm{U}) /\left(\mathrm{N}_{1} \times \mathrm{N}_{2}\right)$.

${ }^{1}$ FABA questionnaire.

${ }^{2}$ SOC-L9 questionnaire.

${ }^{3}$ Questionnaire of occupational and medical history.

Other abbreviations as in Table 1.

\section{Physical health factors}

There were no differences regarding most of the risk factors for cardiovascular diseases between both teacher groups (Table 2). More than half of the teachers had high blood pressure (51\%), about $40 \%$ were overweight $(29 \%)$ or obese $(12 \%)$ and two-thirds of them had an increased or strongly increased waist circumference (Table 2). On average, the teachers had 2 cardiovascular risk factors. No risk factor was present in $16 \%$ of the whole teacher sample.

The physical fitness of the whole sample could be regarded as favourable with an average pulse performance index (PPI) value of 1.9 (Table 2). The PPI indicated that more than $90 \%$ of all the teachers had a good or normal physical fitness (PPI $\geq 1$ ), whereas $8 \%$ of them had an impaired physical fitness $(\mathrm{PPI}<1)$.

Table 4. Results of the Binary Logistic Regression

\begin{tabular}{|c|c|c|c|c|c|c|c|c|}
\hline \multirow{2}{*}{$\begin{array}{c}\text { Step } 1 \\
\text { Predictors }\end{array}$} & \multirow{2}{*}{$\begin{array}{c}\text { Regression } \\
\text { coefficient } \\
\text { B } \\
\end{array}$} & \multirow{2}{*}{$\begin{array}{c}\text { Standard } \\
\text { error }\end{array}$} & \multirow[b]{2}{*}{ Wald } & \multirow[b]{2}{*}{ df } & \multirow[b]{2}{*}{$\mathrm{p}$} & \multirow[b]{2}{*}{$\operatorname{Exp}(B)$} & \multicolumn{2}{|c|}{$95 \%$ CI for $\operatorname{EXP}(B)$} \\
\hline & & & & & & & lower & upper \\
\hline ERI ratio $(\text { ERI }>1)^{1}$ & 1.223 & 0.360 & 11.54 & 1 & 0.001 & 3.396 & 1.677 & 6.878 \\
\hline Physical complaints (n) (range: $0-41)^{2}$ & 0.067 & 0.022 & 9.26 & 1 & 0.002 & 1.069 & 1.024 & 1.116 \\
\hline Relaxation inability (range: 6-24) $)^{3}$ & 0.077 & 0.039 & 3.92 & 1 & 0.048 & 1.080 & 1.001 & 1.165 \\
\hline Sense of coherence (range: $9-63)^{4}$ & -0.057 & 0.019 & 8.83 & 1 & 0.003 & 0.945 & 0.910 & 0.981 \\
\hline Constant & -1.799 & 1.287 & 1.95 & 1 & 0.162 & 0.165 & & \\
\hline
\end{tabular}

Significance (two-tailed): ${ }^{*} \mathrm{p}<0.05 ;{ }^{*} \mathrm{p}<0.01 ;{ }^{* *} \mathrm{p}<0.001$.

${ }^{1}$ ERI questionnaire.

${ }^{2}$ Questionnaire of complaints.

${ }^{3} \mathrm{FABA}$ questionnaire.

${ }^{4}$ SOC-L9 questionnaire.

$\mathrm{CI}$ - confidence interval. 


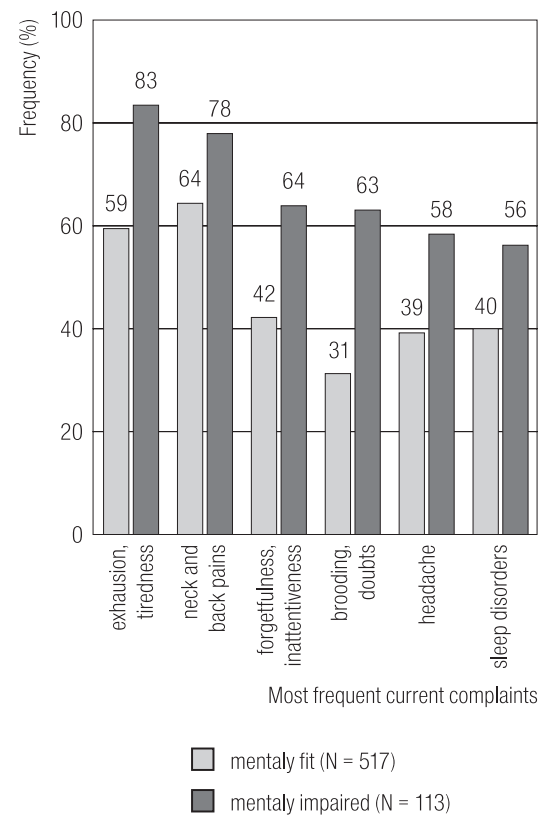

Fig. 1. Current complaints among the mentally fit and mentally impaired teachers

Regarding physical complaints, significant differences between the mentally fit and impaired teachers were determined. With an average of 13 physical complaints, the mentally impaired teachers reported significantly more complaints than the mentally fit ones (average: 7 complaints). For the present sample, exhaustion and tiredness, neck and back pain as well as forgetfulness or inattentiveness appeared to be first rank complaints (Figures 1 and 2).

\section{Personal factors}

The mentally impaired teachers had significantly higher values of relaxation inability and lower values in the sense of coherence score. There were no differences in health behaviour

\begin{tabular}{|c|c|c|}
\hline Effort-reward-ratio (ERI-Q) & \multirow{4}{*}{\begin{tabular}{|l}
$0.067^{* *}$ \\
$-0.057^{* *}$ \\
$0.077^{*}$ \\
\end{tabular}} & \multirow{3}{*}{$\begin{array}{c}\text { Mental health } \\
\text { (sum score GHQ-12) } \\
\text { Fit versus impaired } \\
\text { mental health }\end{array}$} \\
\hline Number of physical complaints (BFB) & & \\
\hline Sense of coherence (SOC-L9) & & \\
\hline Relaxation inability(FABA) & & Exnlained variance. 22 9\% \\
\hline
\end{tabular}

Significance (two-tailed): ${ }^{*} \mathrm{p}<0.05 ;{ }^{* *} \mathrm{p}<0.01 ;{ }^{* *} \mathrm{p}<0.001$.

Fig. 2. Predictors of mental health (binary logistic regression model: beta-coefficients) among the teachers
(Table 3). Regular physical activities were reported by $64 \%$ of the teachers, i.e. a sports activity at least one hour once a week or half an hour twice a week (the minimum of physical activity required for achieving good physical fitness). In this sample, only $46 \%$ of the teachers reporting regular physical activities demonstrated very good physical fitness (PPI > 2).

\section{Predictors of mental health}

Binary logistic regression analyses were carried out to test the influence of the work-related, physical health and personal factors on the mental health of teachers. First, all examined working conditions (volume of employment, additional activities, extra-curricular activities, preparation and follow-up of lessons, size and level of classes, volume of school lessons, weekly total working hours) and the scales of occupational effort and reward were tested as possible predictors of mentally fit $\left(\mathrm{MH}^{+}\right)$versus mentally impaired teachers $\left(\mathrm{MH}^{-}\right)$. Then, the predictive values of the physical health (cardiovascular risk factors, number of physical complaints) and the personal factors (relaxation inability, sense of coherence, health behaviour, including age) were tested. As the last step, all conditions were analyzed in a combined model.

In the regression analyses, the working conditions explained only $2 \%$ of the variance between the mentally fit and mentally impaired teachers and the ERI subscale alone explained $7 \%\left(\mathrm{R}^{2}=0.075\right)$. In the case of physical health factors $14 \%$, and in the case of personal characteristics (relaxation inability and the sense of coherence) $17 \%\left(R^{2}=0.166\right)$ of the variance could be explained between both teacher groups. In the combined model (Figure 2, Table 2), the variables ERI ratio, physical complaints and personal characteristics proved to be relevant predictors of mental health and elucidated a variance proportion of $23 \%\left(\mathrm{R}^{2}=0.226\right)$. Fit mental health was associated with a more favourable ERI ratio, a low number of physical complaints, a good ability to recover and a good sense of coherence. The teachers with impaired mental health showed an ERI ratio above 1 more than 3 times 
$(\mathrm{OR}=3.4)$ as often as the healthy teachers (Table 2). The odds ratios for physical complaints and personal-related factors were significant, but not very meaningful in the case of prediction of impaired health.

It was confirmed that the volume of employment, school type and calendar age do not prove to be predictors of mental health among female teachers.

\section{DISCUSSION AND PRACTICAL IMPLICATIONS}

Teaching profession has been labelled as highly stressful [7,32]. So far, international studies concerning mental health of teachers have indicated relationships between mental health impairments and job-specific straining factors [4-6,12,13,15-17]. The resulting negative consequences demand a comprehensive analysis of the risk factors as well as resources at school in order to find suitable solutions in terms of preventive and intervening measures in the teaching profession.

The findings are based on a sample of 630 female teachers working in German public schools. Mental health was assessed with the German short version of the GHQ-12 [22]. The teacher sample was classified according to the case classification from Üstün and Sartorius [24]. Based on the GHQ-12 sum score $\geq 5,18 \%$ of the teacher sample showed signs of mental health problems. This percentage of teachers with impaired mental health is not higher than in the study by Üstün and Sartorius [24], who examined general population. Using the slightly lower cut-off $\geq 4$ according to the British Heart Foundation [33], $23 \%$ of the teachers are likely to be suffering from some kind of mental health problems. Bauer et al. [21] report that $30 \%$ of their teacher sample (male: $32 \%$, female: 29\%) showed signs of significant mental health problems using the cut-off value $\geq 4$. Beyond these facts, GHQ values vary between populations and countries [23]. A GHQ-12 validity study revealed an equally wide range of best estimates for threshold scores ranging from $0 / 1$ to $5 / 6$ but variation in the best thresholds is unaccounted for Goldberg et al. [34].

The regression analysis of potential predictors identified 4 variables: effort-reward-ratio, number of physical complaints, ability to relax and sense of coherence that explained $23 \%$ of the mental health variance, of which the variable effort-reward-ratio was identified as the main predictor for fit and impaired mental health. That means, this variable had a particularly large impact on mental health. By contrast, the examined 'classic' factors of the working situation, the majority of cardiovascular risk factors and the health behaviour contribute only to a small extent to the explanation of the state of mental health. This effect is not in line with our hypothesis (health and personal factors are just as related to mental health as 'classic' working conditions). There were significant group differences between the mentally fit and impaired teachers regarding the subscales of the ERI ratio. The teachers with impaired mental health reported a higher ERI ratio $\left(\mathrm{MH}^{-}: 0.8 \pm 0.3 ; \mathrm{MH}^{+}: 0.6 \pm 0.2\right)$. This effect of a comparably higher effort and a low reward (expressed by low appreciation, job security and money or career opportunities) and impaired mental health was confirmed [35]. There are indications of the known problem of the image of the teaching profession and the great implications of a lack of appreciation on health-related well-being $[6,36]$. This result is supported by the fact that significantly more teachers with impaired mental health belonged to the harmful ERI group $\left(\mathrm{MH}^{+}: 4 \%\right.$; $\left.\mathrm{MH}^{-}: 20 \%\right)$. With an actual ERI ratio $>1$, the chance for the appearance of impaired mental health increases 3.4-fold for teachers (Table 2). This indicates a specific need for prevention measures.

Compared to the ERI ratio, the odds ratios of physical complaints and personal factors were less important predictors of mental health in the teaching profession. However, the teachers with impaired mental health had a higher number of physical complaints and showed a significant complaint pattern, which is characterised especially by exhaustion, tiredness, brooding, doubts, forgetfulness, 
distractibility and sleep disorders (Figure 1). This indicates a psychosomatic context.

Also, the work-related evaluation of effort and reward already includes aspects of subjective complaint perception like rating and coping. With this regard, factors such as: coping, motivation, work satisfaction, working style and social support appear to be promising explanation variables in the scientific studies of health status $[6,17]$. In this study, social components like cooperation with colleagues, parents and school headmasters were not analyzed closely, but could be relevant resources for the teaching profession and thus, should be considered in the future in a more detailed manner.

In summary, the results show a stable mental health condition for the majority of examined teachers (82\%), which is accompanied by a favourable ERI ratio and moderate working conditions. Despite this state of mental health among the teachers, there were health impairments in some of them. Taking into account importance of the teaching profession for pupils and the society, it seems clear that there is a need for action in the shape of suitable prevention and intervention programmes. There are some starting points for supportive measures. They are to be found in demands and resources of the occupational conditions as well as in personal coping style but also in social and personal surroundings, especially in special health complaint patterns, occupational effort-reward-ratio and the ability to recover. In order to improve reputation of teachers, the importance of their pedagogical work and their educational responsibility have to receive greater emphasis in the public dialogue.

\section{Strengths and limitations}

A limitation of this study is its cross-sectional design, which is only able to describe correlations but is unable to prove causality. Moreover, the limitations of the instruments must be considered. The data in the used questionnaires are based on self-reports which may be biased by effects of social desirability. According to the GHQ-12 questionnaire, the literature mentions different cut-offs for the identification of cases, and cut-offs usually vary in different studies ranging from 4 to 6 [37], depending on the evaluation strategy.

The results might have been affected by the response bias because the mean participation rate was $73 \%$. The limitations of representativeness of this study may be caused by the fact that our teacher sample was a regional sample from the area of Saxony, Germany. Therefore, this study sample cannot be considered to be representative of all German teachers. In Germany, teacher recruitment and education is organised differently in several federal states. Thus, extrapolations must be made with caution. In order to draw conclusions with respect to German teachers in general, comparative studies with other federal states are necessary. Furthermore, it has to be considered that this study was only able to assess a part of relevant professional demands in the occupational history. Social components, like cooperation with colleagues, parents, the school headmaster and pupils, as well as performance and behavioural problems of the pupils, the importance of which regarding stress in the teaching profession is acknowledged, were not presented. Yet, it can be assumed that health and personal preconditions are rather relevant factors for the analysis of risks and resources of the teaching profession. The importance of the ERI ratio could be correlated with the fact that the estimation of the ERI balance in a job already contains aspects of the subjective complaint perception and coping. Therefore, especially factors like coping, selfefficacy, motivation, work satisfaction, the way of working and social support prove to be promising variables in scientific research [5, 9,19,38,39].

\section{Key points}

1. Impaired mental health could be found in $18 \%$ of the teacher sample. The teachers with fit mental health are significantly different from those with impaired mental 
health by a favourable ERI ratio, a lower number of physical complaints, a better ability to recover after work and a stronger sense of coherence.

2. Contrary to the expectations, the examined "classic" characteristics of the working situation are not relevant predictors of mental health in the teaching profession. The effort-reward-ratio proves to be the most relevant predictor of mental health of teachers, and in addition, physical complaints and personal factors proved to be relevant.

3. The identified predictors should become a part of preventive arrangements for the conservation of teachers' health in the future. The measures focused on health promotion and improving working conditions may also affect work-related stress positively.

\section{ACKNOWLEDGMENTS}

The data were collected as part of the nationwide network project "Health promotion for teachers" that is a part of a model programme for combating work-related diseases. As a matter of legal succession, it is funded by the Federal Ministry of Labour and Social Affairs while its technical and scientific guidance is in the hands of the Federal Institute for Occupational Safety and Health (BAuA) in Berlin.

\section{REFERENCES}

1. Stansfeld S, Candy B. Psychosocial work environment and mental health - A meta-analytic review. Scand J Work Environ Health. 2006;32:443-62.

2. Bonde JPE. Psychosocial factors at work and risk of depression: a systematic review of the epidemiological evidence. Occup Environ Med. 2008;65:438-45.

3. Bauer J, Stamm A, Virnich K, Wissing K, Müller U, Wirsching $\mathrm{M}$, et al. Correlation between burnout syndrome and psychological and psychosomatic symptoms among teachers. Int Arch Occup Environ Health. 2006;79:199-204.
4. Hillert A, Schmitz E, editors. [Psychosomatic diseases in female and male teachers. Causes, concepts, prevention, therapeutical approaches]. Stuttgart: Schattauer; 2004. German.

5. Seibt R, Matz A, Hegewald J, Spitzer S. Working conditions of female part-time and full-time teachers in relation to health status. Int Arch Occup Environ Health. 2012;85:675-87.

6. Unterbrink T, Hack A, Pfeifer R, Buhl-Grießhaber V, Müller $\mathrm{U}$, Wesche $\mathrm{H}$, et al. Burnout and effort-reward-imbalance in a sample of 949 German teachers. Int Arch Occup Environ Health. 2007;80:433-41.

7. Kyriacou C. Teacher stress: directions for future research. Educ Rev. 2001;53:27-35.

8. Kovess-Masféty V, Sevilla-Dedieu C, Rios-Seidel C, Nerrière $\mathrm{E}$, Chan Chee $\mathrm{C}$. Do teachers have more health problems? Results from a French cross-sectional survey. BMC Public Health. 2006;21:101-4.

9. Darmody M, Smyth E. Job satisfaction and occupational stress among primary school teachers and school principals in Ireland. A report compiled by the Economic and Social Research Institute (ESRI) on behalf of the Teaching Council. Dublin: Teaching Council; 2010.

10. Zurlo MC, Pes D, Siegrist J. Validity and reliability of the effort-reward imbalance questionnaire in a sample of 673 Italian teachers. Int Arch Occup Environ Health. 2010;83:665-74.

11. Verhoeven CH, Kraaij V, Joekes K, Maes ST. Job conditions and wellness/health outcomes in Dutch secondary school teachers. Psychol Health. 2003;18:473-87.

12. Bellingrath S, Weigl T, Kudielka BM. Chronic work stress and exhaustion is associated with higher allostastic load in female school teachers. Stress. 2009;12:37-48.

13. Brown J, Gilmour WH, Macdonald EB. Ill health retirement in Scottish teachers: process, outcomes and re-employment. Int Arch Occup Environ Health. 2006;79:433-40.

14. Chaudhury N, Hammer JS, Kremer M, Muralidharan K, Rogers FH. Missing in action. Teacher and health worker absence in developing countries. J Econ Perspect. 2006;20:91-116. 
15. Dunham J, Varma V. Stress in teachers: Past, present and future. London: Whurr Publishers; 1998.

16. European Trade Union Committee for Education (ETUCE). Teachers' work-related stress: European-wide survey - assessment, comparison and evaluation of the impact of psychosocial hazards on teachers at their workplace in the EU. Brussels: European Trade Union Committee for Education; 2011.

17. Montgomery C, Rupp AA. A meta-analysis for exploring the diverse causes and effects of stress in teachers. Canad J Educ. 2005;28:458-86.

18. Pervez S, Hanif R. Levels and sources of work stress among women school teachers. Pakistan J Psychol Res. 2003;18: 97-108.

19. Wiley C. A synthesis of research on the causes, effects, and reduction strategies of teacher stress. J Instr Psychol. 2000;27:80-7.

20. Von Känel R, Bellingrath S, Kudielka BM. Overcommitment but not effort-reward imbalance relates to stress-induced coagulation changes in teachers. Ann Behav Med. 2009;37:20-8.

21. Bauer J, Unterbrink T, Hack A, Pfeifer R, Buhl-Grießhaber V, Müller U, et al. Working conditions, adverse events and mental health problems in a sample of 949 German teachers. Int Arch Occup Environ Health. 2007;80:442-9.

22. Linden M, Maier W, Achberger M, Herr R, Helmchen H, Benkert $\mathrm{O}$. [Mental diseases and their therapy in general practitioners in Germany]. Nervenarzt. 1996;67:205-215. German.

23. Goldberg DP, Gater R, Sartorius N, Üstün TB, Piccinelli M, Gureje O, et al. The validity of two versions of the GHQ in the WHO study of mental illness in general health care. Psychol Med. 1997;27:191-7.

24. Üstün TB, Sartorius N. Mental illness in general health care: An international study. New York: Wiley and Sons; 1995.

25. Siegrist J, Starke D, Chandola T, Godin I, Marmot M, Niedhammer I, et al. The measurement of effort-reward imbalance at work: European comparisons. Soc Sci Med. 2004;58:1483-99.

26. Seibt R, Dutschke D, Hübler A, Scheuch K. [Guideline for individual preventive occupational-medical and psychological check-up among teachers. The Dresden Model]. Dresden: Selbstverlag der Technischen Universität Dresden; 2007. German.

27. Höck K, Hess H. [The questionnaire for complaints]. Berlin: Deutscher Verlag der Wissenschaften; 1975. German.

28. Richter P, Rudolf M, Schmidt CF. [Questionnaire for analysis of stress-related coping with job demands]. Göttingen: Huber: 1996. German.

29. Schumacher J, Wilz G, Gunzelmann T, Brähler E. [Antonovsky's Sense of Coherence Scale - its validation in a population-based sample and the development of a new short scale]. Psychother Psych Med. 2000;50:472-82.

30. Rudolf M, Müller J. Multivariate Verfahren. [Multivariate methods. A practical introduction with application examples in SPSS.] (2. Aufl.). Göttingen: Hogrefe; 2012.

31. Cohen J. Statistical power analysis for the behavioral sciences. 2nd ed. Hillsdale: Lawrence Erlbaum Associates; 1988.

32. Al-Fudail M, Mellar H. Investigating teacher stress when using technology. Comput \& Educ 2008;51:1103-10.

33. British Heart Foundation 2006. Health Survey for England (2005). [Online-report] [cited 2013 Oct 10]. Available from URL: http://www.heartstats.org.

34. Goldberg DP, Oldehinkel T, Ormel J. Why GHQ threshold varies from one place to another. Psychol Med. 1998;28: 915-21.

35. Taris TW, Peeters MC, Le Blanc PM, Schaufeli WB, Schreus PJ. From inequity to burnout: The role of job stress. J Occup Health Psychol. 2001;6:303-23.

36. Van Vegchel N, de Jonge J, Bosma H, Schaufeli W. Reviewing the effort-reward-imbalance model: Drawing up the balance of 45 empirical studies. Soc Sci Med. 2005;60:1117-31.

37. Goldberg DP, Williams P. A user's guide to the General Health Questionnaire. Windsor: NFER-Nelson; 1998.

38. Schaarschmidt U, Fischer AW. [Patterns of coping in employment. Differences in personality in dealing with work load]. Göttingen: Vandenhoeck \& Ruprecht; 2001.

39. Unterbrink T, Zimmermann L, Pfeifer R, Rose U, Joos A, Hartmann A, et al. Improvement in school teachers' mental 
health by a manual-based psychological group program. Psychother Psychosom. 2010;79:262-4.

40. Guidelines for the Treatment of Arterial Hypertension. German Hypertension League; German Society for Hypertension and Prevention. (Stand: 01.06.2008) [cited 2012 Nov 1]. [Online-report]: Available from: http://www. awmf. org/leitlinien/detail/1/046-001.html.
41. German Adiposity Association, German Diabetes Association, German Association for Nutrition (2005). Evidence based Guideline - Prevention and Therapy of Adiposity (2007). (Stand: 01.06.2008). [cited 2012 Nov 1] [Online-report]: Available from: http://www. awmf.org/ leitlinien/ detail/1//046-001.html.

This work is available in Open Access model and licensed under a Creative Commons Attribution-NonCommercial 3.0 Poland License - http://creativecommons.org/ licenses/by-nc/3.0/pl/deed.en. 